\title{
Elderly Quality of Life and Its Predictors in Chronic Disease Management Program: Indonesian Version of WHOQOL-BREF and WHOQOL-OLD
}

\author{
Melly Lionthina, ${ }^{1}$ Guswan Wiwaha, ${ }^{2}$ Sharon Gondodiputro, ${ }^{2}$ Insi Farida Desy Arya, ${ }^{2}$ Hadyana Sukandar, ${ }^{2}$ \\ Deni K. Sunjaya ${ }^{2}$ \\ ${ }^{1}$ Bangka District Health Office, Bangka Belitung Province, Indonesia, \\ ${ }^{2}$ Department of Public Health Faculty of Medicine Universitas Padjadjaran Bandung, Indonesia
}

\begin{abstract}
Indonesia is currently experiencing increasing proportion of older population, which also increases the prevalence of chronic diseases that may decrease the quality of life (QoL). The Indonesian Social Security Agency develops a program to control chronic diseases, which is referred to as the Chronic Disease Management Program (Program Pengelolaan Penyakit Kronis, PROLANIS) for the National Health Insurance participants. Its goals is to control chronic diseases in order to improve participants' QoL. To evaluate the QoL of the elderly, the World Health Organization (WHO) has developed two questionnaires, namely WHOQOL-BREF and WHOQOL-OLD. The objective of this study was to analyze the differences in the QoL of the elderly between PROLANIS and nonPROLANIS participants using the Indonesian-verson of WHOQOL-BREF and WHOQOL-OLD as well as the QoL predictors. A cross-sectional study was carried out to 84 elderly PROLANIS participants $(\mathrm{n}=42)$ and non-PROLANIS participants $(\mathrm{n}=42)$. Respondents were sampled consecutively from 6 public health health centers (Pusat Kesehatan Masyarakat, Puskesmas) in Bangka District, Indonesia in 2018. Mann Whitney test or the unpaired T test were used to statistically analyze the difference between the two groups. A multiple linear regression test was then carried out to determine the predictors of the QoL. This study discovered that no difference was observed in the QoL of the elderly between PROLANIS and non-PROLANIS participants. Disease status and depression were the predictors of the QoL. Therefore, PROLANIS has not been proven to be able to improve the QoL of the elderly.
\end{abstract}

Key words: Elderly, PROLANIS, QoL, WHOQOL-BREF, WHOQOL-OLD

\section{Kualitas Hidup Lanjut Usia dan Prediktornya pada Program Pengelolaan Penyakit Kronis: Versi Indonesia dari WHOQOL-BREF dan WHOQOL-OLD}

\begin{abstract}
Abstrak
Peningkatan proporsi penduduk lanjut usia (lansia) di Indonesia meningkatkan prevalensi penyakit kronis, sehingga dapat menyebabkan penurunan kualitas hidup. Badan Penyelenggara Jaminan Sosial mengembangkan Program Pengelolaan Penyakit Kronis (PROLANIS) bagi peserta Jaminan Kesehatan Nasional dengan tujuan agar penyakit kronis tersebut terkontrol dan lansia dapat hidup berkualitas. World Health Organization (WHO) mengembangkan instrumen untuk mengukur kualitas hidup, yaitu WHOQOL-BREF dan WHOQOL-OLD. Penelitian ini bertujuan menganalisis perbedaan kualitas hidup lanjut usia antara bukan peserta PROLANIS dan peserta PROLANIS dengan menggunakan kuesioner WHOQOL-BREF dan WHOQOL-OLD versi Bahasa Indonesia dan faktor yang berpengaruh. Penelitian potong lintang dilakukan pada 84 lansia yang terbagi menjadi 2 grup masing-masing 42 responden, yaitu bukan peserta PROLANIS danpeserta PROLANIS. Responden berasal dari 6 Puskesmas di Kabupaten Bangka Provinsi Bangka Belitung Indonesia pada tahun 2018 yang dipilih sesuai kriteria inklusi dan dengan metode consecutive sampling. Data yang terkumpul dilakukan analisis menggunakan Uji Mann Whitney atau uji T tidak berpasangan. Uji regresi linier multipel dilakukan untuk menentukan prediktor dari kualitas hidup. Hasil penelitian menunjukkan bahwa tidak ada perbedaan kualitas hidup lansia antara bukan peserta PROLANIS danpeserta PROLANIS. Status penyakit dan depresi merupakan prediktor kualitas hidup. Simpulan, PROLANIS belum terbukti dapat meningkatkan kualitas hidup lansia.
\end{abstract}

Kata kunci: Kualitas hidup, lanjut usia, PROLANIS, WHOQOL-BREF, WHOQOL-OLD

Corresponding Author: Sharon Gondodiputro, Department of Public Health Faculty of Medicine Universitas Padjadjaran, Jalan Prof. Eyckman No. 38 Bandung, West Java, Indonesia, Email: sharon_gondodiputro@yahoo.com 


\section{Introduction}

Indonesia is one of the countries in Southeast Asia that is experiencing an increase in the older population. A report from the Southeast Asia Regional World Health Organization office estimates that Indonesia will have the largest proportion of elderly people in the Southeast Asia region. In 2012, the proportion of elderly in this country was $8.5 \%$, which will increase dramatically to $26 \%$ in $2050{ }^{1}$

The elderly are susceptible to various chronic diseases. The results of The Indonesian Basic Health Research in 2018 showed that some chronic diseases such as diabetes mellitus, coronary heart disease, stroke, and chronic kidney failure are identified among the elderly above 75 years old was with the proportions of $3.3 \%, 4.7 \%, 50.2 \%$, and $0.75 \%$, respectively. ${ }^{2}$

The increase in the prevalence of chronic diseases in the elderly requires a comprehensive health care service. The Indonesian Social Security Agency for Health has developed a Chronic Disease Management Program which is referred to as PROLANIS for the National Health Insurance (JKN) participants since 2015. ${ }^{3}$ The objective of this program is to encourage JKN participants who suffer from chronic diseases, especially hypertension and Diabetes mellitus, to be able to achieve the optimum quality of life (QoL). ${ }^{3}$

The World Health Organization (WHO) defines QoL as "an individual's perception of their position in life in the context of the culture and value systems in which they live and in relation to their goals, expectations, standards, and concerns". ${ }^{4}$ To measure the elderly's QoL, The WHOQOL Group has developed two instruments, namely WHOQOL-BREF and WHOQOL-OLD which consist of 4 facets and 6 facets, respectively. ${ }^{4,5}$ The WHOQOL-BREF has been translated to Indonesian by $\mathrm{R}$ Mardiati et al. and revised by FD Purba. ${ }^{6}$ Meanwhile, the WHOQOL-OLD has been translated to Indonesian by S. Gondodiputro et al. and has been reported elsewhere.

The effectiveness of the PROLANIS to improve the QoL of the elderly has never been measured by using the WHOQOL-BREF and WHOQOL-OLD instruments. For this reason, this study aimed to analyze differences in the QoL of the elderly between PROLANIS-participants and nonPROLANIS participants, as measured using the Indonesian version of the WHOQOL-BREF and WHOQOL-OLD, and its predictors.

\section{Methods}

An analytic study with a cross-sectional design was carried out to 84 respondents. sampled consecutively, who were divided into 2 groups: group $1(n=42)$ that consisted of non-PROLANIS participants and group $2(n=42)$ that consisted of PROLANIS participants. This study had been approved by the Ethics Committee of Universitas Padjadjaran Bandung, Indonesia, through the issuance of the ethical clearance No. 890/UN6. $\mathrm{KEP} / \mathrm{EC} / 2018$. The inclusion criteria of the respondents were aged $\geq 60$ years old; female or male; PROLANIS participants or not PROLANIS participants; visit the Public Health Center (Pusat Kesehatan Masyarakat, Puskesmas) to seek treatment; able to communicate, read and write in Indonesian; and did not have dementia as proven by a Mini-Mental State Examination (MMSE) score of $\geq 22$. The exclusion criteria were eligible elderly people who did not agree to be the respondent in this study.

This study was conducted in 6 Puskesmas in Bangka District from October to November 2018. Eleven variables were included in respondent characteristic data: age (60-70 years and $\geq 70$ years group); gender (male and female); education (junior high school or lower and high school or higher); marital status (unmarried, married, and widower/widowed); occupation (not working and working); income ( $\geq$ IDR 2,500,000 and <IDR 2,500,000); living arrangements (living alone, living with a spouse, living with a spouse and other members or family, and living with other family members); physical activity ( $>1$ time a week and $\leq 1$ time a week); social participation ( $\geq 3$ times a week and $<3$ times a week); depression (non-depression with a Geriatric Depression Scale score $\leq 4$ and possible depression and depression with a Geriatric Depression Scale score $\geq 5$ ); and status of current disease (no disease, one disease, two diseases, and more than two diseases and/or symptoms). The statistical tests used to compare the characteristics of the two study groups were the 2x2 table Chi-square test and KolmogorovSmirnov test for the $\mathrm{Kx} 2$ table.

Two QoL instruments were used in this study, namely the Indonesian version of the WHOQOLBREF and WHOQOL-OLD. The WHOQOL-BREF instrument consists of 26 questions with 2 general questions and 24 questions about QoL. ${ }^{4}$ WHOQOL-BREF instrument has 4 facets, namely 1) physical health, 2) psychological, 3) social relationships, and 4) environment. ${ }^{4}$ Similar to the WHOQOL-BREF instrument, The WHOQOL- 
M Lionthina, et al: Elderly Quality of Life and Its Predictors in Chronic Disease Management Program: Indonesian Version of WHOQOL-BREF and WHOQOL-OLD

Table 1 Characteristics of Respondents in Group 1 and Group 2

\begin{tabular}{|c|c|c|c|}
\hline Characteristics & $\begin{array}{c}\text { Group } 1 \\
\mathrm{n}=42(\%)\end{array}$ & $\begin{array}{c}\text { Group } 2 \\
\mathrm{n}=42(\%)\end{array}$ & p-value \\
\hline \multicolumn{4}{|l|}{ Age (years) } \\
\hline $60-70$ & $38(90.5)$ & 39 (92.9) & .693 \\
\hline$>70$ & $4(9.5)$ & $3(7.1)$ & \\
\hline \multicolumn{4}{|l|}{ Gender } \\
\hline Male & $16(38.1)$ & $12(28.6)$ & .355 \\
\hline Female & $30(71.4)$ & $26(61.9)$ & \\
\hline \multicolumn{4}{|l|}{ Education } \\
\hline Junior high school or lower & $31(73.8)$ & $30(71.4)$ & .807 \\
\hline Senior high school or higher & $11(26.2)$ & $12(28.6)$ & \\
\hline \multicolumn{4}{|l|}{ Occupation } \\
\hline Not working & $25(59.5)$ & $22(52.4)$ & .510 \\
\hline Working & $17(40.5)$ & $20(47.6)$ & \\
\hline \multicolumn{4}{|l|}{ Income } \\
\hline$<$ IDR $2,500,000$ & $19(45.2)$ & $27(64.3)$ & .124 \\
\hline$\geq$ IDR $2,500,000$ & $23(54.8)$ & $15(35.7)$ & \\
\hline \multicolumn{4}{|l|}{ Marital status } \\
\hline Not married & $1(2.4)$ & $0(0.0)$ & \\
\hline Married & $28(66.7)$ & $27(64.3)$ & $1.000^{\mathrm{b}}$ \\
\hline Widow/widower & $13(31.0)$ & 15 (35.7) & \\
\hline \multicolumn{4}{|l|}{ Living arrangement } \\
\hline Alone & $3(7.1)$ & $4(9.5)$ & \\
\hline With spouse & $8(19.0)$ & $6(14.3)$ & $1.000^{\mathrm{b}}$ \\
\hline $\begin{array}{l}\text { With spouse and other family } \\
\text { member/s }\end{array}$ & $20(47.6)$ & $21(50.0)$ & \\
\hline With family member/s & $11(26.2)$ & $11(26.2)$ & \\
\hline \multicolumn{4}{|l|}{ Physical activity } \\
\hline sonce a week & $10(23.8)$ & $9(21.4)$ & .794 \\
\hline >once a week & $32(76.2)$ & $33(78.6)$ & \\
\hline \multicolumn{4}{|l|}{ Social participation } \\
\hline$\leq$ three times a week & $13(31.0)$ & $14(33.3)$ & .815 \\
\hline >three times a week & $29(69.0)$ & $28(66.7)$ & \\
\hline \multicolumn{4}{|l|}{ Depression } \\
\hline No depression & $36(85.7)$ & $35(83.3)$ & .763 \\
\hline Expected depression and depression & $6(14.3)$ & 7 (16.7) & \\
\hline \multicolumn{4}{|l|}{ Disease/Symptom } \\
\hline No disease/symptom & $2(4.8)$ & $3(7.1)$ & \\
\hline One disease/symptom & $9(21.4)$ & $10(23.8)$ & $1.000^{\mathrm{b}}$ \\
\hline Two diseases/symptoms & $15(35.7)$ & $13(31.0)$ & \\
\hline$>$ Two diseases/symptoms & $16(38.1)$ & $16(38.1)$ & \\
\hline
\end{tabular}

Notes: ${ }^{b}$ Kosgomorov-Smirnow statistical test 
M Lionthina, et al: Elderly Quality of Life and Its Predictors in Chronic Disease Management Program: Indonesian Version of WHOQOL-BREF and WHOQOL-OLD

Table 2 Difference between Group 1 and Group 2 in Four Facets of WHOQOL-BREF

\begin{tabular}{|c|c|c|c|}
\hline WHOQOL-BREF & $\begin{array}{c}\text { Group } 1 \\
(n=42)\end{array}$ & $\begin{array}{c}\text { Group } 2 \\
(n=42)\end{array}$ & p-value \\
\hline \multicolumn{4}{|l|}{ Physical health } \\
\hline Median & 63.00 & 56.00 & \multirow{3}{*}{$.094^{\mathrm{a}}$} \\
\hline Minimum & 31.00 & 38.00 & \\
\hline Maximum & 88.00 & 94.00 & \\
\hline \multicolumn{4}{|l|}{ Psychological } \\
\hline Mean & 61.83 & 66.12 & \multirow{2}{*}{$.149^{\mathrm{b}}$} \\
\hline SD & 12.87 & 14.05 & \\
\hline \multicolumn{4}{|l|}{ Social relationship } \\
\hline Median & 56.00 & 56.00 & \multirow{3}{*}{$.150^{\mathrm{a}}$} \\
\hline Minimum & 25.00 & 25.00 & \\
\hline Maximum & 94.00 & 94.00 & \\
\hline \multicolumn{4}{|l|}{ Environment } \\
\hline Mean & 59.33 & 62.76 & \multirow{2}{*}{$.235^{\mathrm{b}}$} \\
\hline SD & 12.33 & 13.92 & \\
\hline
\end{tabular}

notes: SD= standard deviation; ${ }^{a}$ Mann-Whitney statistical test; ${ }^{\mathrm{b}}$ Unpaired t-test; median, minimum and maximum values provided with the normality test results in mind (shapiro-wilk test)

OLD instrument consists of 26 items with 2 general items and 24 items about QoL. ${ }^{5}$ The 24 items are divided into 6 facets: sensory abilities; autonomy; past, present and future activities; social participation; death and dying; and intimacy. ${ }^{5}$ In this study, each item was scored with a Likert scale (1 to 5) and the raw scores of each facet or the total raw scores were transformed into a 0-100 scale using tables for converting individual raw scores to transformed scores. ${ }^{4,5}$ Before statistical tests were performed, the transformed scores of the WHOQOL-BREF and WHOQOL-OLD were tested for normality using the Shapiro-Wilk test. Analysis of differences in QoL between the two groups was performed using the Mann Whitney test or the unpaired T-test. Step-wise multiple linear regression analysis was used to simultaneously determine the impact of 11 characteristic variables on the QoL.

\section{Results}

This study involved 84 respondents who were divided into 2 groups: 42 non-PROLANIS participants (Group 1) and 42 PROLANIS participants (Group 2). Table 1 showed that no difference was observed in the characteristics of respondents between Group 1 and Group 2. This showed that both groups were homogeneous.

The results of the normality test using the Shapiro-Wilk revealed that the transformed scores for physical health and social relationships were not normally distributed $(\mathrm{p}<0.05)$, while the scores for psychological and environment were normally distributed ( $p>0.05)$. This study discovered that of the 4 WHOQOL-BREF facets, the social relationship facet had the lowest score when compared to other facets with a score of 56. Analytical testing using the Mann-Whitney test or Unpaired t-test showed that there was no difference in the QoL between Group 1 and Group 2 for all facets of the WHOQOL-BREF instrument ( $p>0.05)$.

The results of the transformed scores for each facet and the total score from WHOQOLOLD were tested for normality using the Shapiro-Wilk. The transformed scores from sensory abilities, autonomy, and total score were normally distributed ( $p>0.05)$, whereas past, present, and future activities; social participation; death and dying; and intimacy were not normally distributed $(\mathrm{p}<0.05)$. Of the 6 facets in the WHOQOL-OLD instrument, the facet that had the lowest score was autonomy in both Group 1 and Group 2 (53.43 and 56.99, respectively). A similar result was obtained when the facets of both groups were tested for the differences. There was no difference in the QoL between Group 1 and Group 2 for all facets of the WHOQOL-OLD instrument. ( $p>0.05)$

To identify the 11 variables that had significant impacts on the QoL of the elderly, the step-wise multiple linear regression was performed. Table 4 showed that the predictor 
M Lionthina, et al: Elderly Quality of Life and Its Predictors in Chronic Disease Management Program: Indonesian Version of WHOQOL-BREF and WHOQOL-OLD

Table 3 Differences between Group 1 and Group 2 in Six Facets of The WHOQOL-OLD

\begin{tabular}{|c|c|c|c|}
\hline \multirow{2}{*}{ WHOQOL-OLD } & Group 1 & Group 2 & \multirow{2}{*}{ p-value } \\
\hline & $(n=42)$ & $(n=42)$ & \\
\hline \multicolumn{4}{|l|}{ Sensory abilities } \\
\hline Mean & 64.44 & 67.11 & \multirow{2}{*}{$.476^{\mathrm{b}}$} \\
\hline SD & 16.36 & 17.90 & \\
\hline \multicolumn{4}{|l|}{ Autonomy } \\
\hline Mean & 53.43 & 56.99 & \multirow{2}{*}{.318} \\
\hline SD & 16.05 & 15.75 & \\
\hline \multicolumn{4}{|c|}{ Past, present, and future activities } \\
\hline Median & 62.50 & 68.75 & \multirow{3}{*}{$.417^{\mathrm{a}}$} \\
\hline Minimum & 43.75 & 31.25 & \\
\hline Maximum & 93.75 & 93.75 & \\
\hline \multicolumn{4}{|l|}{ Social participation } \\
\hline Median & 62.50 & 65.62 & \multirow{3}{*}{$.583^{\mathrm{a}}$} \\
\hline Minimum & 37.50 & 37.50 & \\
\hline Maximum & 100.00 & 93.75 & \\
\hline \multicolumn{4}{|l|}{ Death and dying } \\
\hline Median & 75.00 & 75.00 & \multirow{3}{*}{$.272^{\mathrm{a}}$} \\
\hline Minimum & 25.00 & 12.50 & \\
\hline Maximum & 100.00 & 100.00 & \\
\hline \multicolumn{4}{|l|}{ Intimacy } \\
\hline Median & 75.00 & 75.00 & \multirow{3}{*}{$.547^{a}$} \\
\hline Minimum & 25.00 & 0.00 & \\
\hline Maximum & 100.00 & 100.00 & \\
\hline \multicolumn{4}{|l|}{ Total Score } \\
\hline Mean & 65.06 & 65.92 & \multirow{2}{*}{$.691^{\mathrm{b}}$} \\
\hline SD & 10.48 & 9.43 & \\
\hline
\end{tabular}

Notes: $\mathrm{SD}=$ standard deviation; ${ }^{\text {a }}$ Mann-Whitney statistical test; ${ }^{\mathrm{b}}$ Unpaired t-test; median, minimum and maximum value provided with the normality test results in mind (Shapiro-Wilk test)

variables with significant impacts on the QoL of the elderly by using WHOQOL-BREF instrument were diseases/symptoms and income. The $\beta$ values of the disease/symptoms and income variables were -0.329 and 0.276 respectively. The adjusted R2 was 0.141 only for diseases/ symptoms and 0.205 for the two variables. Those variables account for 20.5 percent of variations in the dependent variable.

The results of multiple linear regression in the QoL of the elderly by using the WHOQOLOLD instrument showed that the diseases/ symptoms and depression were the predictors of the QoL of the elderly with $\beta$ values of -0.334

Table 4 Step-wise Selection Multiple Linear Regression Model with WHOQOL-BREF Total as Dependent Variable

\begin{tabular}{|c|c|c|c|c|c|c|c|}
\hline \multirow[t]{2}{*}{ Model } & \multirow[t]{2}{*}{ Independent Variable } & \multicolumn{2}{|c|}{$\begin{array}{l}\text { Unstandardized } \\
\text { Coefficients }\end{array}$} & \multirow[t]{2}{*}{$\boldsymbol{\beta}$} & \multirow[t]{2}{*}{$\mathbf{t}$} & \multirow[t]{2}{*}{ Sig } & \multirow{2}{*}{$\begin{array}{l}\text { Adjusted } \\
\mathbf{R}^{2}\end{array}$} \\
\hline & & B & SE & & & & \\
\hline \multirow[t]{2}{*}{1} & (Constant) & 74.690 & 3.679 & & & & .141 \\
\hline & Diseases/Symptoms & -4.432 & 1.160 & -.389 & -3.821 & .000 & \\
\hline \multirow[t]{3}{*}{2} & (Constant) & 64.222 & 5.194 & & & & .205 \\
\hline & Diseases/Symptoms & -3.748 & 1.143 & -.329 & -3.279 & .002 & \\
\hline & Income & 5.826 & 2.116 & .276 & 2.754 & .007 & \\
\hline
\end{tabular}

Notes: Dependent variable: WHOQOL-BREF; Significant at $\mathrm{p}<0.05$ 
M Lionthina, et al: Elderly Quality of Life and Its Predictors in Chronic Disease Management Program: Indonesian Version of WHOQOL-BREF and WHOQOL-OLD

Table 5 Step-wise Selection Multiple Linear Regression Model with WHOQOL-OLD Total as Dependent Variable

\begin{tabular}{|c|c|c|c|c|c|c|c|}
\hline \multirow[t]{2}{*}{ Model } & \multirow[t]{2}{*}{ Independent Variable } & \multicolumn{2}{|c|}{$\begin{array}{c}\text { Unstandardized } \\
\text { Coefficients }\end{array}$} & \multirow[t]{2}{*}{$\boldsymbol{\beta}$} & \multirow[t]{2}{*}{$\mathbf{t}$} & \multirow[t]{2}{*}{ Sig } & \multirow{2}{*}{$\begin{array}{c}\text { Adjusted } \\
\mathbf{R}^{2}\end{array}$} \\
\hline & & B & SE & & & & \\
\hline \multirow[t]{2}{*}{1} & (Constant) & 77.784 & 3.481 & & & & .132 \\
\hline & Diseases/Symptoms & -4.050 & 1.097 & -.377 & -3.690 & .000 & \\
\hline \multirow[t]{3}{*}{2} & (Constant) & 83.196 & 4.261 & & & & .167 \\
\hline & Diseases/Symptoms & -3.589 & 1.097 & -.334 & -3.273 & .002 & \\
\hline & Depression & -5.898 & 2.785 & -.216 & -2.117 & .037 & \\
\hline
\end{tabular}

Notes: Dependent variable: WHOQOL-OLD; Significant at $\mathrm{p}<0.05$

and -0.216 respectively. However, the Adjusted R2 value generated by these 2 variables was quite low, i.e. $16.7 \%$.

\section{Discussion}

Chronic Disease Management Program (PROLANIS) is a health service system developed by The Indonesian Social Security Agency for the National Health Insurance (JKN) participants who suffer from chronic diseases. ${ }^{3}$ The purpose of this program is to achieve optimum QoL among the participants. ${ }^{3}$ The activities undertaken in this program are medical consultations; health education to increase knowledge on efforts to control the disease and improve health status; the SMS Gateway as a reminder for the consultation schedule; and home visits to provide information/education on individual and environmental health of the participants and their families ${ }^{3}$

This study shows that PROLANIS has not been proven to improve the QoL of the elderly as stated in the objectives of this program. This is because PROLANIS seems only to intervene in the physical aspects, such as those seen in hypertension and diabetes ${ }^{3}$ while achieving optimum QoL requires interventions from various facets, including the mental, cognitive, functional, and socioeconomic ${ }^{4,5}$ Of the four facets of the WHOQOL-BREF instrument, the social relationship has the lowest score compared to other facets. Components of social relationships are personal relationships, social support, and sexual activities. ${ }^{4}$ A study conducted by Bélanger et al. ${ }^{7}$ has discovered that relationships with partners, children, and friends are associated with good health status. Social relationships increase the physical and psychological health, as well as maintaining functional abilities. ${ }^{8-10}$. The elderly people are similar as the adults in terms of sexual activities but changes or decreases in activity can occur due to decreased health status, hormonal decline, the presence or absence of partners, and the quality of relationships with partners. ${ }^{11,12}$

This study discovered that autonomy has the lowest score compared to other facets of WHOQOL-OLD instruments. This is in line with a study by MHP de Paiva. ${ }^{13}$ The autonomy of the elderly decreases because the elderly find it difficult to make decisions as they are more likely to depend on others. ${ }^{13}$ Multifactors contribute to achieving optimal QoL for the elderly, but in this study the main predictors are income, depression and disease status. The majority of people in Bangka District work in the agricultural sector such as pepper, rubber, and oil palm plantation. The income earned from selling agricultural products is not worth the hard work of the farmers. Moreover, the declining selling prices also affect their income. Income as a predictor of QoL is still a controversy. A study by Campos et al., ${ }^{14}$ showed that income is linked to QoL, but a study Soósová $\mathrm{MS}^{15}$ revealed that income is not related to QoL.

Depression is a mental disorder that often occurs in the elderly and is a major cause of disability. ${ }^{16,17}$ A study by Ju and $\mathrm{Kim}^{18}$ discovered that depression affects the QoL of the elderly. This result is in line with a study by Weber et al. ${ }^{19}$ however, depression that occurs in the elderly is not the only factor that decreases QoL.In this study, most of the elderly had 2 or more than 2 diseases/symptoms. This health condition can cause disruption of daily activities, limited ability to move, and difficulty in working. ${ }^{20}$

This study has limitations. The frequency and the compliance of attendance at the PROLANIS activities were not identified. This situation can have an impact on the QoL. Data collection was carried out when the elderly were seeking treatment so that they had limited time to 
answer the questions that might have an impact on the score of the QoL. Moreover, there is no cut-off point score that pointed to the QoL of the elderly. Furthermore, the value of the adjusted R2 is quite low, so there are still other factors that influence the QoL model of the elderly that have not been identified.

It can be concluded that there is no difference between the QoL of PROLANIS and nonPROLANIS participants in Bangka District, Bangka Belitung Archipelago Province. The most prominent predictor factor is depression and disease status. The activities in PROLANIS need to be improved to not only include measures to control chronic diseases but also improve the QoL of the elderly in various facets.

\section{References}

1. WHO-Regional Office for South-East Asia. Regional strategy for healthy ageing (20132018), Regional Office for South-East Asia. New Delhi: WHO-SEARO; 2014.

2. Indonesian Ministry of Health. Laporan nasional Riskesdas 2018. Jakarta: Badan Penelitian dan Pengembangan Kesehatan Kemenkes RI; 2018.

3. BPJS Kesehatan. Panduan Praktis PROLANIS (Program Pengelolaan Penyakit Kronis) [Internet]. Jakarta: BPJS Kesehatan; 2015. Available from: https://bpjskesehatan.go.id/bpjs/dmdocuments / a9c04aa825ffc12d24aeee668747f284.pdf

4. World Health Organization. WHOQOL-BREF, Introduction,administration, scoring and generic version of the assessment. Geneva: Programme on Mental Health WHO; 1996.

5. World Health Organization. WHOQOL-OLD Manual. Copenhagen: WHO-European Office; 2006.

6. Purba FD, Hunfeld JAM, Iskandarsyah A, Fitriana TS, Sadarjoen SS, Passchier J, et al. QoL of the Indonesian general population: Test-retest reliability and population norms of the EQ-5D-5L and WHOQOL-BREF. PLoS One. 2018;13(5):1-20.

7. Bélanger E, Ahmed T, Vafaei A, Curcio CL, Phillips SP, Zunzunegui MV. Sources of social support associated with health and QoL: A cross-sectional study among Canadian and Latin American older adults. BMJ Open. 2016;6(6):1-10.

8. Chang P-Y, Wray L, Lin Y. Social relationship, leisure ctivity, and health inolder adults. 2014;33(6):516-23.
9. Hajek A, Brettschneider C, Mallon T, Der Leeden C Van, Mamone S, Wiese B, et al. How does social support affect functional impairment in late life? Findings of a multicenter prospective cohort study in Germany. Age Ageing. 2017;46(5):813-20.

10. Liu J, Rozelle S, Xu Q, Yu N, Zhou T. Social engagement and elderly health in China: Evidence from the China health and retirement longitudinal survey (CHARLS). Int J Environ Res Public Health. 2019;16(2):278.

11. Omole F, Fresh EM, Sow C, Lin J, Taiwo B, Nichols M. How to discuss sex with elderly patients. J Fam Pract. 2014;63(4):1-4.

12. Dhingra I, De Sousa A, Sonavane S. Sexuality in older adults: Clinical and psychosocial dilemmas. J Geriatr Ment Health 2016;3(2): 131-9.

13. de Paiva MHP, Pegorari MS, Nascimento JS, Santos Á da S. Factors associated with QoL among the elderly in the community of the southern triangle macro-region, Minas Gerais, Brazil. Cienc e Saude Coletiva. 2016;21(11):3347-56.

14. Campos ACV, F Ferreira e Ferreira E, Vargas AMD, Albala C. Aging, gender and QoL (AGEQOL) study: Factors associated with good QoL in older Brazilian communitydwelling adults. Health Qual Life Outcomes. 2014;12(1):1-11.

15. Soósová MS. Determinants of QoL in the elderly. Cent Eur J Nurs Midwifery. 2016;7(3):484-93.

16. Sözeri-Varma G. Depression in the elderly: clinical features and risk factors. Aging Dis. 2012;3(6):465-71.

17. Van Nguyen T, Van Nguyen H, Duc Nguyen T, Van Nguyen T, The Nguyen P. Difference in QoL and associated factors among the elderly in rural Vietnam. J Prev Med Hyg. 2017;58(1):E63-71.

18. Ju S, Kim K-S. The Relationship among QoL, depression and subjective health status of the elderly with chronic disease in Korea. Indian J Sci Technol. 2015;8(16):1-8.

19. Weber K, Canuto A, Giannakopoulos $P$, Mouchian A, Meiler-Mititelu C, Meiler A, et al. Personality, psychosocial and health-related predictors of QoL in old age. Aging Ment Health. 2015;19(2):151-8.

20. Steptoe A, Fancourt D. Leading a meaningful life at older ages and its relationship with social engagement, prosperity, health, biology, and time use. Proc Natl Acad Sci U S A. 2019;116(4):1207-12. 